Vol. 8, Issue 1, pp.1-11, February 2020

Published by ECRTD- $U K$

Print ISSN: 2053-4043(Print), Online ISSN: 2053-4051(Online)

\title{
DIGITAL MARKETING SERVICES ENHANCE BUSINESS PERFORMANCE GOALS BY PROMOTING PRODUCTS AND SERVICES TO CONSUMERS: A DIGITAL APPROACH
}

\author{
Dr. Asma Zaheer \\ Assistant Professor, Department of Marketing, \\ Faculty of Economics and Business Administration, \\ King Abdulaziz University, Jeddah- Saudi Arabia (ameraj@kau.edu.sa)
}

\begin{abstract}
The study focus on determining the effect of Digital Essentials tools for promoting products and services to enhance business performance. The digital marketing SMART objectives benchmarked against the existing competitors to ensure effectiveness for achieving the organizational goals. Digital marketing mix utilises marketing techniques, lead generation, social media and website optimization. Digital essentials include targeting and cost effectiveness to promote the product to the needy people at the proper time. Facebook page and QR codes have more influence on the consumer's behavior as a marketing tool. Content plays very important role for website in attracting potential customers in near future and Flow content is very useful for acquisition and amplification. There are many issues related to online purchase, but the most important concerns of the buyers/customers are: cancellation and refund. Therefore, an organization takes special interest in sorting out such issues. In conclusion the digital essential tools effect business $p$ and promote products and services.
\end{abstract}

KEYWORDS: digital marketing, consumers, products, services and business.

\section{DIGITAL MARKETING DEFINITION}

Chaffey (2007), defines digital marketing as technologies which make marketing ventures to achieve profit and hold customers. Digital Marketing involves Online Advertising, Emailmarketing, Search Engine Optimization (SEP), Social Media Marketing, Content Marketing, Branding, etc. (Fig No -1) 


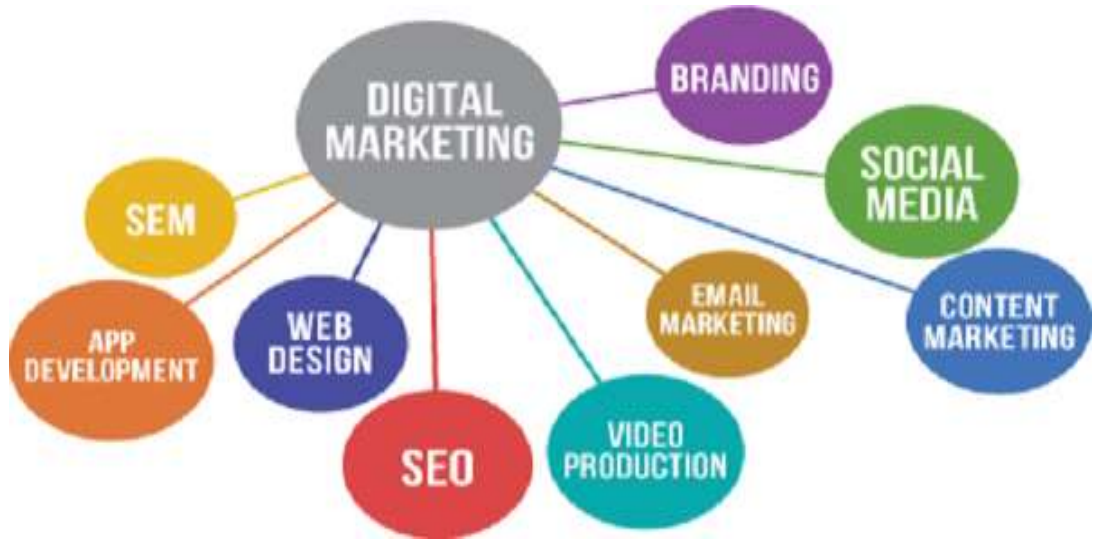

\section{Digital Marketing Objectives}

The compulsory objectives of digital are SMART (Specific, Measurable, Achievable, Relevant and Time Related); and it should benchmarked against the existing competitors to ensure effectiveness. (Fig No-2)

\section{SMART Marketing Objectives}

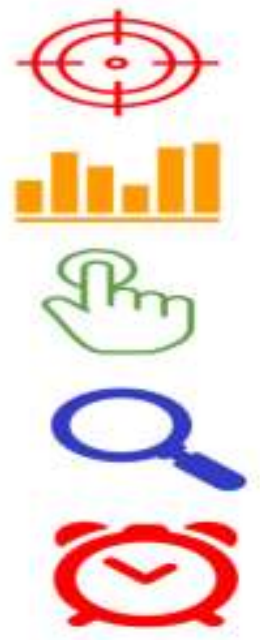

Specific

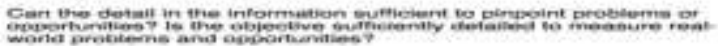

Measureable

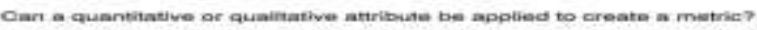

Actionable

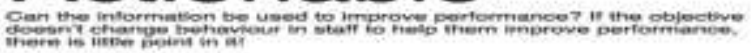

Relevant

Oan the information be mpolied to the mpecine protien taosed by thes
marketer?

\section{Time-bound}

\section{Digital Marketing Mix}

The digital marketing mix is not much different from the marketing mix. It is nothing but an adaptation of price, place, product in addition to the promotion and marketing. Digital marketing mix utilises marketing techniques, lead generation, social media and website optimization (Fig No-3) 
Vol. 8, Issue 1, pp.1-11, February 2020

Published by ECRTD- $U K$

Print ISSN: 2053-4043(Print), Online ISSN: 2053-4051(Online)

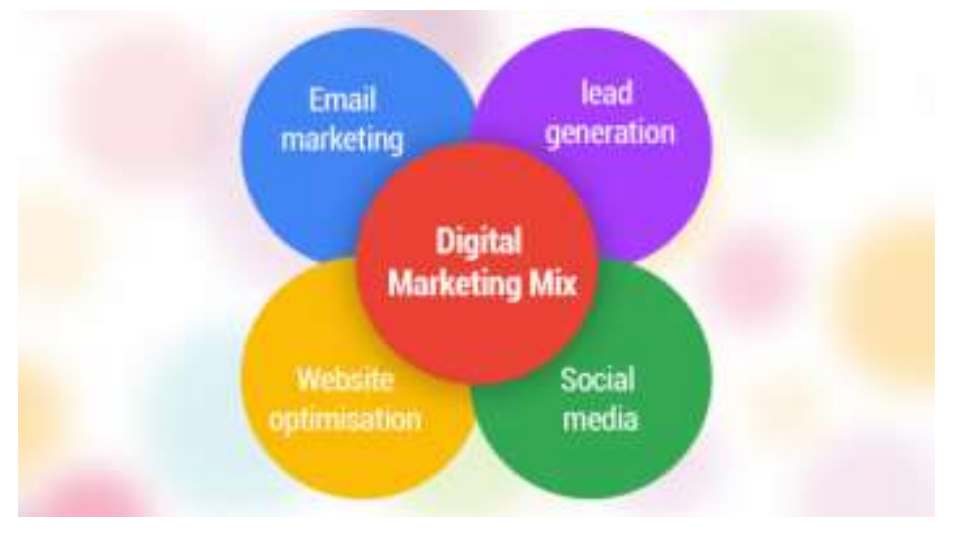

\section{Digital Marketing Benefits}

In order to encourage the existing customers there is a need to understand the differences between these two promotional strategies: online and offline content design. Many companies work on both marketing to create brand awareness and reach out to the audiences.

\section{Online Marketing:}

Networked marketing is the activity of observing the consumer through specific banners, images, videos articles and more placed on the front page of website.

Offline Marketing:

Offline marketing is the procedure to generate brand attention to reach the selected consumer for their wants and needs of satisfaction

Differences: There are many differences between the two modes of marketing: online and offline (quora.com). Following is the summary of differences between offline and online marketing:

\begin{tabular}{|l|l|}
\hline Online marketing & Offline marketing \\
\hline 1-It is more cost-effective & Not cost effective \\
\hline 2- Less entry barriers & Entry barriers \\
\hline 3-Fast moving & Not fast moving \\
\hline 4-More targeted & Less targeted \\
\hline
\end{tabular}

\section{Targeting}

Targeting can be defined as the action of selecting a specific market with advertising or marketing or both. Targeting is considered as an essential part for most of the businesses. Targeting in marketing can be well utilized as a strategy that aims to breaks a large market into smaller 
Vol. 8, Issue 1, pp.1-11, February 2020

Published by ECRTD- UK

Print ISSN: 2053-4043(Print), Online ISSN: 2053-4051(Online)

parts which allows the marketing expert to target a specific group of customers. On the other hand, 'Traditional marketing techniques' are less likely to be targeted because of its limitations especially cost effectiveness and narrower scope (businessdictionary.com). Traditional method of advertising/marketing as done by even TV ads (Kingsnorth, 2016), are not likely to talk directly to the customers or add any details of a previous enquiry unlike digital marketing. In other words, direct talks or instant feedback can be exploited to channelize interaction with the target customers through emails or social platforms like facebook. E-mails can connect with the customers on a personal level like 'Pull Marketing' which can involve the use of pull tactics, or the communication of information, to attract the customer' (study.com). This is a great opportunity by digital marketing for making the content more targeted and streamline your marketing message to promote the product to the needy people at the proper time which will lead to more customers.

\section{Cost Effective}

Traditional marketing uses print ads on, newspapers and magazines, flyers, TV /radiocommercials, billboards etc. On the other hand, digital marketing basically depends on a website, promotes on social media and uses other digital instruments of all possible types. The recurring costs in traditional marketing can prove to be a huge investment that may or may not yield a good return. In addition, an ad in a local newspaper will only be one time effective if it is noticed by the target audience on the day it gets published, but the chances are quite bleak.

The way in which digital marketing differs from traditional marketing in terms of cost is that it is considered as the most profitable technique to market the business' (lyfemarketing.com). As regards the conventional marketing, it's very tough for tiny companies because these have limited finances to fight with big businesses in order to get enough space for ads.

For example, a graph as cited by lyfemarketing.com shows that small scale companies display over 1,000 consumer to its services and products for less than $\$ 3$ utilizing social media on the other side similar exposure by direct mail costs about $\$ 57$ and reached through ads television value about $\$ 28$ which clearly shows that traditional marketing methods are costly as compared to digital marketing. (Fig No-4) 
Vol. 8, Issue 1, pp.1-11, February 2020

Published by ECRTD- UK

Print ISSN: 2053-4043(Print), Online ISSN: 2053-4051(Online)

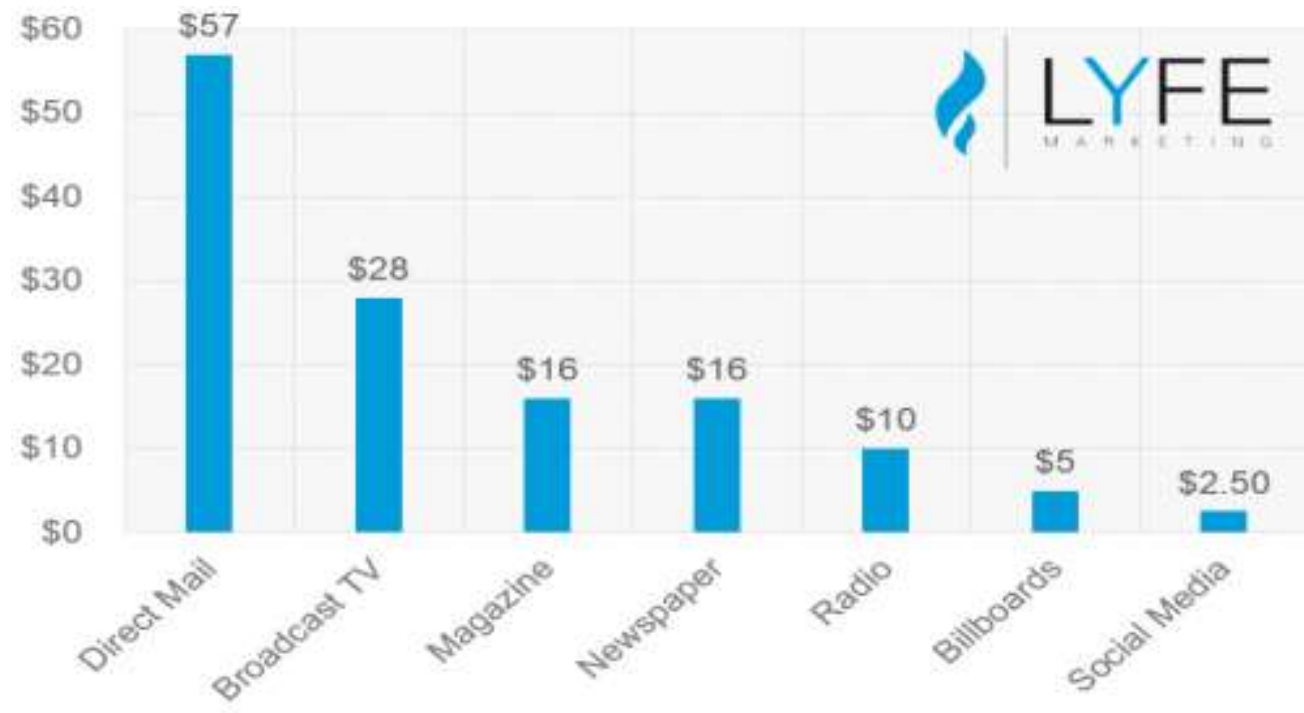

(Source: lyfemarketing.com)

\section{Email- Marketing}

Email marketing is a great way to contact customers directly to grow connection with potential clients and/or consumers. It keeps well informed to its consumers regarding marketing updated messages, as it goes straight to their inbox and one can make it 'personalized' (thebalancesmb.com). Due to the latest GDPR legislation, "it is now a requirement to receive the customers' consents to opt in on any literature that you send to them" (gdpr-legislation.co.uk).This is a great feature as the customers will be interested in the products based on the analysis of ant thing bad for the companies. One can send emails on weekly basis to the people who have already signed into marketing communications. Once the customer has opted in to email communications newsletters, promotional deals and personalised emails can be sent to them.

\section{Landing Pages}

Landing pages can play very important role in marketing of a product. Landing page designs are more than just a sign-up form on a homepage. So, it is essential to make a list of landing pages. As a substitute of a many pages challenging the consumer need just one landing page quality is sufficient to begin and promote new ideas. It captures and tracks good marketing guide. It also provides direct path for contacting the potential clients which will be needed to contact/connect the existing clients at the time of the launch of a new product. 
Vol. 8, Issue 1, pp.1-11, February 2020

Published by ECRTD- UK

Print ISSN: 2053-4043(Print), Online ISSN: 2053-4051(Online)

\section{Facebook}

The page of Facebook for an individual or a business is the most common way to represent an individual or a business. They can stay connected 24/7 through machines including computers, iPads, laptops and mobiles. It is considered as a cost-effective strategy by many businesses to communicate with consumers (Nelson-Field et al., 2012). Therefore, it should be utilized as a crucial platform for marketing in the form of groups, pages and ads. Heijden and Verhagen (2002) contend that researches in the area of a popular trend in present decision for online purchasing indicate that purchasing from stores which are important for a 'new economy'. Thus, online shopping or purchase is becoming quite popular trend for doing shopping (Heijden et al., 2003). Researches are indicative of the trend as to how current social media in general and facebook in particular influence behavior of the target consumers/customers. In this connection, it has been noticed that shopping prompted by social media is on the rise. But, the research reminds us that there are many other more important communications that first influence consumer behaviour. Bizrate's trend tracker survey demonstrates how online customers are exploiting a medium like facebook when they decide to buy products after engaging themselves in surveys or seeking public opinion. In this regards, findings show that Facebook still ranks high for 'shopping related activities' for online shoppers (smartinsights.com/digital-marketing).As Facebook affects friendsconsumers and facebook users are quite closely related on daily basis, and their primary motto is sharing, therefore facebook can affect the buyers' behaviour too. According to Nielson report (2010), 'the option of 'like', 'check-in' or 'share' has a significant influence on purchase decisionmaking. In this regards, Harris and Dennis (2011) indicate that it is very common to find customers being influenced more by their family and friends than any other way. Advertising on facebook permit dealers to guide users into the "awareness" stage, which leads consumers to the "buy" phase (socialmediaweek.org). (Fig No-5)

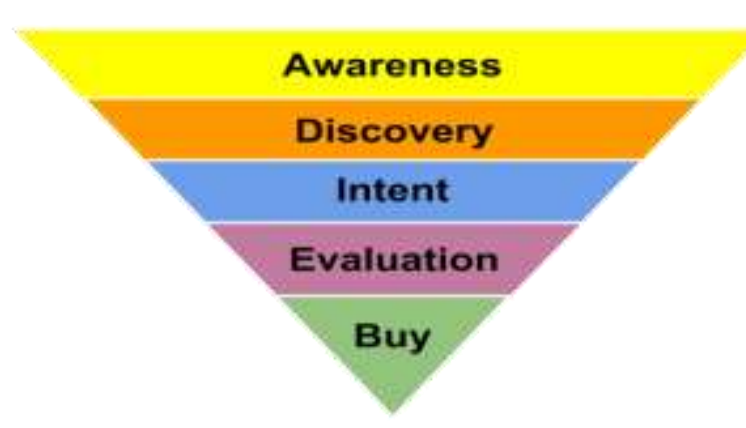

\section{QR Code}

There are few papers related to QR codes in the field of mobile marketing. A novel study was carried out for the first time in India by Narang, Jain and Roy (2012) exploring the influence QR 
Vol. 8, Issue 1, pp.1-11, February 2020

Published by ECRTD- UK

Print ISSN: 2053-4043(Print), Online ISSN: 2053-4051(Online)

Codes on consumers behavior with reference to certain marketing and advertising activities including their attitude towards the advertisement, point of view in the direction of buying intentions. The findings of the study are supported by these authors (Mitchell, 1981; Kassarjian, 1981; Mittal \& Lee, 1989), where researchers have emphasized that the consumers spend more time in the search evaluation process of high involvement product categories. It has further been noted that greater level awareness of QR codes have more impact on the consumers behavior as this can act as a marketing instrument, particularly in the high participation of product category, where the decision making seeks more and useful information, good news is that different details can be accessed through smart-phones. QR Code can exert significant influence on advertising, marketing and consumer behaviour in many ways. Narang, Jain and Roy (2012) are of the opinion that QR codes are creating waves in this area of mobile marketing. Thayer (2012) in his doctoral thesis found that quick response (QR) codes have been introduced corresponding to the increased use of smart phones and other mobile devices equipped with sophisticated cameras. QR codes allow large amounts of data such as product information, offers, discounts etc. To access business related information or a product, consumers/customers have to scan the QR code with a smart device like smartphones. Besides, $\mathrm{QR}$ code use is made simple and explained for motivational purposes. Examples of motivators include discounts only available through a QR code and similar incentives.

\section{Blogs}

Blogs are very important in marketing and advertising especially in digital marketing communication mix. However, content plays very important role in attracting the readers who could be potential customers in near future. It is said that the content of a new blog will be the bait to attract the clients (firstsiteguide.com).

The content part has the following components which the blog writer has to consider before finalizing the block: pre-launch and post-launch contents.

These follow:

Pre-launch content depends on the static pages such as "About," "Contact," etc. It also has sidebar content: content that appears on the sidebar of the intended blog.

\section{Post-launch content}

It has been noticed that around $48 \%$ of Top 100 Blogs are managed with Word Press. Blog posts will contain regular articles or features that blog writer is going to focus about the products for marketing sake.

Importance of blog contents to promote trial and usage of the products 
Vol. 8, Issue 1, pp.1-11, February 2020

Published by ECRTD- $U K$

Print ISSN: 2053-4043(Print), Online ISSN: 2053-4051(Online)

In order to promote marketing of a product, online presence is a must for blogging platform. By having an ecommerce store, one can integrate a blogging platform. It is a known fact that writing blog posts about new products will surely attract more and new customers to the site which the blog writer can utilize to make prospective buyers aware about the launched product and ensure more sales.

The blog writing process will focus on the following points for trial and usage of a product:

\section{Announcement of New Product Availability}

One can put out a blog post for your new product that includes information and details about the quality of the product itself, how it was made, it's availability, pricing, where to buy it, etc.

\section{How was product Made}

People are very interested by origin stories especially how the product was made. It includes the source of new product, people behind it coming to realization, the actual manufacturing process etc.

\section{What Problems Does The Product Solve?}

One has to keep a list of different problems that the target product may solve. This is going to connect people with the product.

\section{Features of the Product}

One has to highlight the features of the newly launched product. The blog writer can tie those features with the customer's benefits so that they can feel benefitted.

\section{Describe Perfect Scenarios}

People are often found to relate themselves with the stories. They think as if they are part of the story themselves; therefore, it is very crucial for blog writing to focus on the perspective or the scenario that can connect directly to the readers/customers/future clients. 
Vol. 8, Issue 1, pp.1-11, February 2020

Published by ECRTD- UK

Print ISSN: 2053-4043(Print), Online ISSN: 2053-4051(Online)

\section{Content is the most important parts of a website.}

Stock content -is a design in the format of long form" or "static" content such as lengthy papers something like a highlighted paper which can be traced on one's own media. It is usually employed by organisation webpage and on a mobile (contentum.co.za).

Stock content is like a durable content that reflects the original one, and builds value over time as well expects people to return to the business. Therefore, it is often considered as 'destination' content. Using stock content may be an entertaining experience. Since it is very informative it can be used like a guide or booklet containing different information. A simple example of stock content is an article written by a brand or an organisation which rank is still very high till date which continues to attract regular users to the brand

Flow Content- is 'short attractive streams' which is normally small and compact. Such phrases are called 'snack' content which are available on "earned media" which are social media networks. Contents on these platforms or social sites go 'viral' as a result of responding (including encouraging). Definition "earned media" is when consumers are converted in to channel and start doing the marketing for organisation (contentum.co.za).

The role of flow content is to highlight and amplify the organization 'stock content'. They work hand in hand together as 'flow content' is an instant grab of attention through sharable content such as images and videos, which can then direct any customers to the stock content if they wish to engage further. 'Flow content' is strategies of attention grabbing which may initiate the customer to engage with you further (econsultancy.com).

\section{Flow content is very useful for Development}

The purpose of flow content is to remind that you exist. The more the flow content the more powerful method to gain customers, In sum, Stock content is found more expensive to be created and used. In this type, more direct message to manage which are used as a channel. Stock is thought of as a great commercial web series. Flow, which is on the another side, is time bound and almost same for significance in time. 'Flow' is characterised by fast updates that remind us of a powerful and speedy mode of communication (blog.percolate.com).

Example: If we use social media in general, and facebook and twitter in particular to market 'Comfort taxi service' the strategy will be the result yielding and instant. It will influence the target audience more. It will also not cost much money. Moreover, ads can be change or modified further keeping the response in view. 
British Journal of Marketing Studies (BJMS)

Vol. 8, Issue 1, pp.1-11, February 2020

Published by ECRTD- UK

Print ISSN: 2053-4043(Print), Online ISSN: 2053-4051(Online)

Example: Hinge Marketing

Flow: On the website of Hinge you will find that there is a facility of an award-winning blog. The organisation also provide outstanding monthly newsletters by using Facebook, Twitter, and LinkedIn which regularly provide a flow of standard content that shows their understanding and proficiency in order to attract the buyers.

Stock: If one takes a look at the library of Hinge marketing, it can be evident through investigation reports, podcasts and whitepapers and the company has communicate the most remarkable book on their topic too - see the shoot up of book which is indeed extremely impressive.

\section{CONCLUSION}

The study shows that a digital approach of using digital tools will definitely effect the consumer behavior for promoting products and services as all digital tools are target oriented with attractive features to have an effect on business performance.

\section{References}

Chris Thayer (2012) Consumer Attitudes towards Using QR Codes in a Retail Setting, thesis, Otterbein University.

https://socialmediaweek.org/blog/2017/05/social-media-influencing-purchase-decisions/ (Accessed on $23^{\text {rd }}$ Sept 2019)

Field. N, K., Riebe, E. \& Sharp, B. (2012), "What's not to "like?" Can a Facebook fan base give a brand the advertising reach it needs?" Journal of Advertising Research, vol. 52, no. 2, pp. 262-269.

Harris, L. \& Dennis, C. (2011), "Engaging customers on facebook: Challenges for eretailers". Journal of Consumer Behaviour, vol. 10, no. 6, pp. 338-346.

https://www.lyfemarketing.com/blog/benefits-digital-marketing/

(Accessed on $10^{\text {th }}$ Sept

https://www.smartinsights.com/digital-marketing-strategy/shopping-activities-using-socialmedia-infographic/ (Accessed on $20^{\text {th }}$ Nov 2019)

https://www.thebalancesmb.com/online-marketing-2948352(Accessed on $25^{\text {th }}$ Sept 2019)

https://www.quora.com/What-are-some-of-the-best-practices-to-create-desire-for-a-new-productservice (Accessed on $27^{\text {th }}$ Sept 2019)

https://econsultancy.com/what-is-stock-and-flow-content-and-how-should-you-use-it (Accessed on $29^{\text {th }}$ Sept 2019)

http://www.onlydeadfish.co.uk/only_dead_fish/2014/01/defining-stock-and-flow-content.html (Accessed on $2^{\text {nd }}$ Oct 2019)

https://blog.percolate.com/2012/03/content-and-the-internet/(Accessed on 22 ${ }^{\text {nd }}$ Oct 2019)

https://hingemarketing.com/ (Accessed on $4^{\text {th }}$ Dec 2019)

https://www.techopedia.com/definition/24747/cybersecurity(Accessed on $5^{\text {th }}$ Dec 2019)

https://www.mindtools.com/pages/article/smart-goals.htm (Accessed on $7^{\text {th }}$ Dec 2019) 
Vol. 8, Issue 1, pp.1-11, February 2020

Published by ECRTD- $U K$

Print ISSN: 2053-4043(Print), Online ISSN: 2053-4051(Online)

https://www.mikencube.co.uk/5-digital-marketing-objectives-examples/(Accessed on $9^{\text {th }}$ Dec 2019

Kassarjian, H. H. (1981). Low Involvement: A Second Look. In Advances in Consumer Research, Vol. 8, ed. Kent B. Monroe, Ann Arbor, MI: Association for Consumer Research, 31--34Mitchell, A. A., \& Olson, C. J. (1981). Are Product Attribute Beliefs the Only Mediator of Advertising Effects on Brand Attitude?. Journal of Marketing Research,18(August), 318-332.

Mittal, B., \& Lee, M. S. (1989). A causal model of consumer involvement. Journal of Economic Psychology, 10, 363---89.

Narang, Sneha; Jain, Varsha; Roy, Subhadip (2012).International Journal of Mobile Marketing . Vol. 7 Issue 2, p52-64.

Simon. K, 2016. Digital Marketing Strategy: an integrated approach to online marketing. 1st Edition. Philadelphia, PA: Kogan Page. 